\title{
Soft Law, Solid Implementation? The Influence of Precision, Monitoring and Stakeholder Involvement on Norwegian Implementation of Arctic Council Recommendations
}

\author{
Ida Folkestad Soltvedt* \\ Research Fellow, Fridtjof Nansen Institute (FNI), Norway
}

\begin{abstract}
The Arctic Council has been criticized for its lack of legal status and, consequently, the supposedly low level of implementation among member states. Studying Norwegian implementation of six Arctic Council recommendations, this article challenges that view. I start by assuming that international law is not binary, that soft law is not a uniform phenomenon, and that soft law recommendations may entail certain characteristics-precision, monitoring, and stakeholder involvement - that can enhance their implementation nationally. Additionally, malignancy - an important barrier to national implementation - is taken into account. The Norwegian authorities have implemented several of the recommendations studied, and the characteristics are found to have a bearing on the outcomes. However, the absence of malignancy stands out as the most significant condition for achieving national implementation.
\end{abstract}

Keywords: Arctic Council; international law; soft law; national implementation; Norway Responsible Editor: Kristoffer Svendsen, Post-doctoral fellow, K.G. Jebsen Centre for the Law of the Sea, Faculty of Law, University of Tromsø, Norway.

Received: November 2016; Accepted: April 2017; Published: May 2017

\section{Introduction}

During recent debates on the Arctic Council, scholars have highlighted the Council's putative weakness as a soft law body, and generally questioned its effectiveness. ${ }^{1}$ This criticism is largely rooted in a lack of legal bindingness: the Arctic Council does not hold the power to contract or enforce legally binding agreements, nor to apply sanctions against its member states. Its recommendations are only politically binding, whereas domestic follow-up is voluntary. Accordingly, it has been claimed that few incentives for national implementation exist.

${ }^{\star}$ Correspondence to: Ida Fokestad Soltvedt, Fridtjof Nansen Institute (FNI), Norway. Email: ifs@fni.no 


\section{Ida Folkestad Soltvedt}

However, only a few studies have examined how the Council's recommendations actually affect national processes, ${ }^{2}$ or - more broadly - the positive effects of soft law on national implementation. This article explores the extent to which the Norwegian authorities have implemented recommendations from two of the Council's foremost policy contributions: the 2004 Arctic Climate Impact Assessment (ACIA), which put climatechange adaptation on the global agenda; and the 2009 Arctic Marine Shipping Assessment (AMSA), the first and only report to cover shipping throughout the Arctic region. ${ }^{3}$

I start by assuming that international law is not binary, that soft law is not a uniform phenomenon, and that soft law recommendations may entail certain characteristics that enhance their domestic implementation. In particular, I ask how precision, procedures for monitoring state behavior and the involvement of stakeholders in norm development can act as drivers of national implementation. In addition, malignancy - an important barrier to national implementation ${ }^{4}$-is taken into account. Data from interviews and documents indicate that these first three characteristics are relevant to Norwegian implementation, i.e. translating recommendations into action at the national level. However, the absence of malignancy appears to be the most significant condition for achieving implementation.

In the following, I start by clarifying the concept of implementation, and then present my fundamental arguments and how the selected characteristics are expected to affect national implementation. Subsequently, I examine whether the recommendations - three derived from the ACIA and three from the AMSA ${ }^{5}$ - have been implemented, and how their characteristics, as well as malignancy, alone and in interaction, have affected varying outcomes.

\section{What does national implementation entail?}

International commitments usually require behavioral change at the domestic (national) level. National implementation concerns the steps taken to induce those changes. ${ }^{6}$ In accordance with this understanding, national implementation is commonly defined as the process whereby international commitments are translated into action at the domestic level, attempting to steer actors towards specific behaviors. ${ }^{7}$ The definition applied in this article rests on the same principles. Specifically, I take national implementation to include domestically conducted programs or actions in response to soft-law recommendations of the Arctic Council. Indicators of such programs or actions are administrative measures and/or budget allocations. Further, national programs and actions may be initiated in order to influence other states' policies through international organizations and institutions. According to the definition applied here, in order to be considered as national implementation, such chains of events must result from the recommendation in question, and induce certain changes at the national level, before "bouncing" back to the international one. At the international level, this should result in Norwegian initiatives and/or projects being carried out within the relevant organization.

This concept of implementation is closely linked to causality, implying that outputs (in this case, Arctic Council recommendations) affect the behavior of relevant actors, and that it is possible to trace causal mechanisms to show an actual link 
between them. Precisely because of its inherent causality, I have chosen to focus on implementation - not compliance, as commonly studied within the academic literature. Compliance, as opposed to implementation, concerns whether the behavior of states and their actors conforms to international provisions. Compliance may even be accidental, resulting from laws and regulations already initiated, whereas implementation is by definition instrumental in nature. ${ }^{8}$

Of course, the determination of causation is a highly complex issue, and the reader must be aware that only a part of the greater picture is presented here. Still, I believe that focusing on causation lowers the risk of ascribing too much credit to the Arctic Council and is therefore a useful exercise. Now, before moving on to the analysis, a closer look at the phenomenon of international law, and especially soft law, is in order.

\section{The dynamics of international law: Different forms of soft law?}

International law has traditionally been considered a binary phenomenon. ${ }^{9}$ Hard law is understood as obligations that are legally binding, whereas soft law refers to norms that are deliberately non-binding in character, located "in the twilight between law and politics." ${ }^{10}$ When the two are pitted against each other, the former is often favored over the latter. Scholars within strands of legal positivism, for instance, privilege hard law: They consider the legal obligation to be crucial-the one element that distinguishes law from mere norms. By definition, then, "law" becomes binding, and the very concept of "soft law" is rejected. ${ }^{11}$ In line with this view, conventional wisdom holds that the most effective commitments are those which are legally binding.

Recent years have witnessed an upsurge in studies of international law and its effects on state behavior. Through contemporary debates, new perspectives have appeared that challenge the "binary divide". Among the key opponents of the binary view, Abbott and Snidal hold that the hard law/soft law distinction is incorrectly taken as dichotomous. ${ }^{12}$ Instead, international law should be understood as dynamic and a matter of gradation. They portray the broader phenomenon of international law as consisting of three dimensions: obligation - that states or other actors are bound by a rule or commitment, making their behavior subject to scrutiny under international law; precision - that rules unambiguously define the conduct that is required, authorized, or prescribed; and delegation - that third parties are granted authority to implement, interpret, and apply the rules. ${ }^{13}$ According to this understanding, hard law refers to "legally binding agreements that are precise (...) and that delegate authority for interpreting and implementing the law." ${ }^{14}$ The realm of soft law, then, begins once legal arrangements are weakened along these dimensions.

Abbott and Snidal's claims have been both applauded and criticized, but one particularly important lesson can be drawn from their work: Softening may occur in varying degrees, which in turn will have distinct implications for how soft-law agreements are interpreted and implemented. ${ }^{15}$ Hence, soft law is neither fixed nor uniform: it exists in differing forms (as is also the case with hard law). By extension, I argue that the characteristics of a certain soft-law commitment-here I focus on precision, monitoring of state behavior, and stakeholder involvement - can affect national decisions about implementing it. 


\section{Ida Folkestad Soltvedt}

\subsection{Characteristics of the commitment as drivers of national implementation}

The characteristics a commitment holds has not been particularly central to soft-law studies, but is of great relevance to studies of hard law: The three characteristics included in this study - precision, monitoring and stakeholder involvement - have been strongly associated with such agreements, and their presence is considered highly important for national implementation. ${ }^{16}$ In conducting the analysis later in this article, I thus understand them, in line with those earlier works, as involving the following:

Precision refers to "rules that unambiguously establish the conduct they require, authorize, or prescribe." 17 A precise recommendation should specify what is expected - stating the objective and the necessary measures to achieve it. ${ }^{18}$ Precision is important for impact because it reduces the leeway available to states and actors with regard to interpretation and discretion. Hence, domestic implementation is best facilitated by a clear message with minimal possibility for misinterpretation. ${ }^{19}$ In contrast, general rules have several drawbacks. Most importantly, they render meaningful assessment of implementation difficult, as much less work is demanded on the part of states expected to abide by them.

Monitoring of state behavior concerns the obligations of states to report back on national measures to meet a certain recommendation. ${ }^{20}$ Such mechanisms make parties more accountable, particularly if any failure to fulfill obligations is publicly revealed. ${ }^{21}$ Where some sort of monitoring exists, states will usually seek to avoid potential shaming. Monitoring also serves to keep the issue on the national and international agendas. The presence or absence of progress may entail scrutiny at both levels, also enabling NGOs and other actors to challenge governmental positions and exert pressure. ${ }^{22}$

Stakeholder involvement concerns "those actors who are affected by the institution or who are capable of influencing its performance" and, further, who are invited to participate in norm-development processes. ${ }^{23}$ Such involvement is held to be positive, not least because stakeholders may seek to persuade their national decision-makers to implement the norms that they themselves helped create. They therefore contribute to the internalization of international norms, by linking them to domestic policies. Or, stakeholders involved in international norm- development processes-persons/ organizations knowledgeable about the matter in question-may be invited into subsequent domestic processes by the national authorities. Then, there may also be room to influence relevant decision-makers at the national level.

These three characteristics have been well studied in the academic literature, which lends leverage to expectations of their effect on national implementation. Importantly, the three characteristics are particularly relevant in the context of the Arctic Council. Since the ACIA project and especially after 2009, with the release of the 'secondgeneration' AMSA report, the Council has formulated increasingly specific policy recommendations and follow-up actions. ${ }^{24}$ Moreover, after the 2009 AMSA release, one of the most articulated criticisms regarding the Council's effectiveness - the lack of a formal monitoring mechanism—was challenged. 
Current trends within the Council also seem to have a bearing on the composition and involvement of various stakeholders. Through the permanent participants, indigenous peoples' groups play an important role in the policy work of the Council, ${ }^{25}$ although they are sometimes marginalized due to lack of resources. Council observers, by contrast, have much more limited rights. ${ }^{26}$ Additionally, given the Council's expanding agenda, this group cannot be expected to include all relevant stakeholders. Whether other stakeholders have the opportunity to inform policy processes will vary, and is likely to depend on more informal ways of inclusion.

Thus, based on these contextual settings, the question: When present, what bearing do the three above-noted characteristics have on national implementation?

\subsection{Malignancy as an obstacle to national implementation}

But first, one final point on malignancy and its negative effect on national implementation. Essentially, "malignancy" concerns the complex political nature of a given problem and, consequently, the incentive to avoid following commitments. ${ }^{27}$ In terms of national implementation one may thus ask: What accounts for such an incentive? Here, I make use of two explanatory dimensions-- political costs and economic costs.

"Political costs" refers to the divergent preferences among relevant actors that may obstruct implementation. However, within Norwegian High North politics, congruity between the parties in the parliament has become the norm. This is illustrated, inter alia, by the White Paper "Opportunities and Challenges in the High North", which sought to develop a new and comprehensive policy for the area's rich resources, and the firm support accorded to this policy by the Norwegian Parliament. The same held true when the Government presented "Nordkloden" ("Norway's arctic policy") in 2014. As such, opposition or "divergent preferences" tend to stem from groupings outside the political sphere. "Economic costs", on the other hand, refers to the strain that implementation places on financial resources. Here, a rule of thumb is that economic costs exceed potential gains from implementation.

Put briefly, then, and in simple terms: Recommendations that do not invoke political or economic costs are non-malignant; while recommendations that invoke political and/or economic costs are malignant, thus considerably lowering the likelihood of implementation.

\section{Implementing the Arctic Climate Impact Assessment}

When it was presented in 2004, the Arctic Climate Impact Assessment (ACIA) represented a milestone in the Council's history. As the first regional climate change assessment, the ACIA dramatically challenged the global understanding of the Arctic as a "frozen desert," and shed light on the vast and complex transformations underway in the region. ${ }^{28}$ To combat the ongoing climate changes revealed through the ACIA project, recommendations based on two sets of actions were put forth: mitigation, to reduce greenhouse gas (GHG) emissions; and adaptation, to limit the adverse impacts of climate change by developing greater resilience. ${ }^{29}$ 


\subsection{National context and selected recommendations}

At the beginning of the ACIA project in 2000, mitigation already featured on national and international agendas. Through global regimes like UNFCCC, and the Kyoto Protocol in particular, Norway was legally committed to reducing its GHG emissions. Therefore, any change in state behavior concerning mitigation must be viewed within the established context of these frameworks, not the Arctic Council. ${ }^{30}$ However, serious discussion on adaptation had yet to emerge - in fact, adaptation was viewed by some as a highly problematic measure that would compromise efforts to reduce emissions. ${ }^{31}$ Yet, a shift in priorities within the climate regime and the media discourse can be traced, drawing largely on the new knowledge produced by the ACIA. ${ }^{32}$ The ACIA revealed how climate change had already caused severe problems for ecosystems and human communities in the Arctic. Moreover, it recognized that climate change had become inevitable, making adaptation vital. With its unique focus on the Arctic region, the ACIA succeeded in putting adaptation on the global agenda - as well as on the national agenda of Norway.

The first Norwegian White Paper on climate change, released in 1995, focused on GHG emissions, accompanied by mitigation measures aimed at reducing them. ${ }^{33}$ It was only after a new White Paper came in 2001 that adaptation gained momentum. ${ }^{34}$ With regard to the Arctic, adaptation was viewed in the context of the ongoing ACIA process, where Norway occupied a central role. That same year, the Norwegian Ministry of the Environment established a steering committee responsible for the country's ACIA work. In the course of 2001 and 2002, four meetings were held on climate change and its consequences for the Norwegian North. The conclusions of these meetings were forwarded to the international process and the Norwegian state authorities. ${ }^{35}$ As Arctic climate adaptation had received limited attention until the turn of the century, it may be that the ACIA, even before it was finalized, made the topic more central in Norwegian politics. Hence, the focus on adaptation and national measures to implement the following ACIA recommendations:

Table 1. The ACIA recommendations

Help Arctic Residents Adapt: Work closely with Arctic residents, including indigenous and local communities, to help them to adapt and manage the environmental, economic and social impacts of climate change and ultraviolet radiation change. Adaptation needs will vary. Arctic residents may need inter alia enhanced access to information, decision-makers, and institutional capacity building to safeguard their health, culture and well-being.

Adaptive Management, Nature Conservation, and Reduction of Risks: Implement as appropriate, adaptive management strategies for Arctic ecosystems, making use of local and indigenous knowledge and participation, review nature conservation and land and resource use policies and programs, and to the extent possible reduce risks related to infrastructure damage, permafrost degradation, floods and costal erosion, taking into account costs and benefits.

Develop the Arctic in a Sustainable Manner: Recognize that opportunities related to climate change, such as increased navigability of sea routes and access to resources, should be developed and managed in a sustainable manner, including through the consideration of environmental and social impacts and taking appropriate measures to protect the environment, local residents and communities.

Source: Arctic Council, ACIA Policy Document (2004) 


\subsection{National implementation}

Recommendation: Help Arctic residents adapt

The first recommendation, "help Arctic residents adapt," focused on the need for adaptation in the North through better access to information, decision-makers, and institutional capacity for those living in the Arctic. ${ }^{36}$ Of the various Norwegian initiatives related to this recommendation, one national program - NorACIAstands out as an important implementation measure. NorACIA was introduced in 2005 , with responsibility for domestic follow-up of ACIA. ${ }^{37}$ Its mandate was to generate and disseminate knowledge, and to provide the Ministry of the Environment with advice concerning relevant national processes. ${ }^{38}$ Thus, a central information platform was created for Arctic residents and for decision-makers. Several seminars focused on the consequences of climate change related to infrastructure, shipping, Saami industries and societal aspects. ${ }^{39}$ Involved in these meetings were actors from research communities, Saami institutions, and the government administration-at both the national and regional levels. ${ }^{40}$ Yet, the most striking feature of Norwegian implementation measures during this period was the focus on indigenous peoples in the design of adaptation policies. For instance, the 2006 High North Strategy stated: "The Arctic Climate Impact Assessment (ACIA) documents how indigenous peoples have adapted to earlier climate change" and that "the climate change currently taking place may have major impacts on the way of life of indigenous peoples (...)".41 The indigenous dimension of the High North Strategy was further elaborated in the 2007 White Paper, Norwegian Saami Policy, where indigenous knowledge and observation of climate-change adaptation were mentioned as central to following up the ACIA. ${ }^{42}$

How can we explain this positive outcome? In the following discussion (and in the discussion of the other ACIA recommendations), I omit the characteristic of "monitoring," as a reporting system was not established for the ACIA. The focus is therefore on precision, stakeholder involvement and potentially the malignant nature of the issue.

First of all, we see that the recommendation is precise. It states the objective- "to help Arctic residents adapt", with possible measures for achieving this- "enhance access to information, decision-makers, and institutional capacity building". As precision is thought to reduce states' use of interpretation and discretion, it may well be that these aspects helped identify the necessary measures to be taken.

Regarding malignancy, the recommendation does not entail significant political cost. There was already widespread agreement in Norway on the importance of the ACIA and its findings. Moreover, access to information and decision-makers are not measures that require great financial resources. The absence of malignancy may thus have facilitated follow-up actions.

Thirdly, the Arctic Council processes in which the recommendation was developed had involved stakeholders. Particularly indigenous peoples' groups, as permanent participants, were involved in all aspects of the ACIA process, including policy work. ${ }^{43}$ From the start, the focus was therefore directed towards the human dimension of 


\section{Ida Folkestad Soltvedt}

climate change, framed largely as the impacts of climate change on indigenous peoples, their lives and livelihoods. ${ }^{44}$ In the implementation of this specific recommendation, the Saami Council, a permanent participant representing the Saami population, played a role at the national level. Together with the other permanent participants, the Saami Council issued statements urging national governments to act. ${ }^{45}$ Moreover, during initial NorACIA meetings, Saami Council representatives stressed the need for the participation and inclusion of Saami interests. ${ }^{46}$ The Saami Council, thereby, affected the national process by lobbying the national authorities and identifying potential representatives and experts from Saami communities. ${ }^{47}$ Similarly, environmental organizations were included as stakeholders in the Arctic Council norm-development processes. The WWF participated in several ACIA meetings at the international level and, subsequently in certain lobbying activities nationally. Shortly after the release of the ACIA report, a letter was sent to the Norwegian Minister of Foreign Affairs, encouraging national decision-makers to develop and implement adaptation strategies. ${ }^{48}$ Later, the WWF received funding from NorACIA for a factsheet series on the impacts of climate change. Thus, we see that the WWF was also involved in implementing the recommendation. In total, whereas the exact effect of precision is difficult to determine, both stakeholder involvement and the absence of malignancy would appear to have had positive impacts on implementation.

\section{Recommendation: Adaptive management, nature conservation and reduction of risks}

The second ACIA recommendation, "adaptive management, nature conservation, and reduction of risks," involved the following objectives: implementation of adaptive management strategies in cooperation with indigenous peoples; review of nature conservation and land use policies and programs; and reduction of risks related to infrastructure damage, permafrost degradation, floods and coastal erosion. ${ }^{49}$ National measures were also implemented in this case, but principally under NorACIA. As regards nature conservation and the review of such policies, an evaluation of key habitats in Northern Norway and on Svalbard was conducted in 2009 , assessing whether current conservation practices were sufficient, or whether greater efforts were necessary to safeguard biodiversity. ${ }^{50}$ These assessment reports have continued to provide an important framework for the management of protected areas on Svalbard. ${ }^{51}$ In addition, several reports on infrastructure damage, as well as the vulnerability of Norway's northern counties and municipalities to floods and coastal erosion were prepared under the umbrella of NorACIA. ${ }^{52}$

What then can be said of the effects of the three chosen characteristics, plus malignancy, on the outcomes? As the recommendation merely states the objectives of adaptive management, nature conservation and risk reduction, without specifying any measures for achieving them, it is imprecise. However, this imprecision need not have a negative bearing on national implementation - indeed, the vague formulation may have made implementation less challenging.

The positive effect that imprecision may have on implementation is closely linked to the concept of malignancy. By being imprecise, the recommendation does not 
impose economic costs; likewise, formulations like "review" and "reduction of risks" do not invite significant political disagreement. Therefore, it is possible that the lack of precision served to reduce malignancy, in turn easing the implementation process.

Stakeholder involvement, on the other hand, seems to have had a limited effect on the positive implementation outcome here. Although the Saami Council and the WWF were actively involved in Arctic Council processes, we find no indication of their involvement in subsequent national processes. One explanation, especially regarding the Saami Council, may be that the assessment reports were scientific in nature and prepared exclusively by specialists.

Briefly, then: the imprecision of this recommendation seems to have had a positive bearing on the implementation outcome, by lowering the political and economic costs, and thereby malignancy. As previously mentioned, however, the exact effect of precision is difficult to measure, and its absence may also be interpreted as a watering down of the recommendation, requiring less work on part of national authorities, and thereby making implementation much less demanding. Lastly, we find nothing to indicate that stakeholder involvement affected the outcome.

\section{Recommendation: Develop the Arctic in a sustainable manner}

The third recommendation, "develop the Arctic in a sustainable manner," encouraged member states to develop the Arctic sustainably - particularly in relation to the increased navigability of sea routes and access to resources - by protecting the environment, local residents and communities. ${ }^{53}$ However, it did not result in any additional implementation measures nationally. To some extent, this can be explained by previously initiated measures that were consistent with the recommendation, in particular the Management Plan for the Barents Sea and Lofoten Area. Still, that plan came to exclude the human dimension of ecosystem-based management - an important deviation from what was stated in the recommendation. ${ }^{54}$ By extension, the interests of the coastal Saami, who are heavily dependent on productive marine ecosystems and their resources, were not taken into account. This is an important point, as it indicates that further action could have been taken in order to accommodate the recommendation. Why then was nothing done?

Firstly, the recommendation is imprecise. It only states objectives - not measures for achieving them. Of course, when it comes to precision, or lack thereof, the findings have already proven ambiguous, and it is therefore difficult to determine any specific effect. With regard to malignancy, however, we see a more distinct pattern. Although the recommendation would have entailed few specific economic costs, resource exploitation does involve conflicting interests, especially among industrial and environmental groups. In the Arctic, indigenous peoples add a further dimension. Political costs are thus present and, subsequently a certain degree of malignancy.

Regarding stakeholder involvement, the same applies as with the first two recommendations. Indigenous peoples as well as environmental organizations were involved in the Arctic Council norm-development process-but we find no 


\section{Ida Folkestad Soltvedt}

trace of their attempting to influence national processes in relation to this recommendation.

In summary, it is possible that these aspects combined - the lack of precision, the presence of malignancy, and no indications of stakeholders attempting to affect national processes - had an obstructive effect on implementation.

\section{Summary}

For a long time, Arctic adaptation did not feature on international or national agendas. Scant attention was paid to the issue in Norway before the ACIA report. Taking into account this contextual setting and the upsurge in national adaptation measures from 2005, ACIA appears to have served as a key driver and as an agendasetter in Norwegian politics. As for implementation, the Norwegian authorities did initiate measures related to two ACIA recommendations: "help Arctic residents adapt" and "adaptive management, nature conservation, and reduction of risks." However, no additional measures were taken to implement the recommendation "develop the Arctic in a sustainable manner."

The picture is more nuanced when it comes to the impact of the three characteristics chosen for this study, plus malignancy, on implementation outcomes. No clear-cut implications of precision and its effect on implementation were identified. In fact, we can note potential positive influences from both precision and lack of precision: the former, by clarifying necessary measures to fulfill implementation; the latter, by lessening political and economic costs and, thereby, malignancy. In contrast, a consistent pattern was detected in connection with malignancy and its effect on implementation: The presence of malignancy appeared to hinder implementation, whereas the absence of malignancy facilitated positive implementation outcomes. As for the stakeholders involved in the Arctic Council processes, they participated in subsequent national implementation processes only in relation to the first recommendation, "help Arctic residents adapt." However, although this was not evident in connection with the other recommendations, we should not rule out the possible effects on implementation yet.

\section{Implementing the Arctic Marine Shipping Assessment}

A main finding of the ACIA report was the opening of the Arctic Ocean and a possible increase in Arctic marine activity. ${ }^{55}$ To follow up this finding, the AMSA project was launched in 2004, aimed at mapping out shipping volumes in the Arctic marine regions. ${ }^{56}$ When this work was finalized in 2009, the need for uniform international standards matching the Arctic conditions and greater coordination between member states had been identified. ${ }^{57}$ To meet these challenges, member states were given recommendations centering around three themes: enhancing Arctic marine safety, protecting the Arctic peoples and the environment; and building Arctic marine infrastructure. ${ }^{58}$ 


\subsection{National context and selected recommendations}

As a leading maritime nation, Norway had already paid great attention to these issues, and AMSA can hardly be seen as an agenda-setter at the domestic level. With close to 110,000 people working in the maritime sector, and with a value creation equaling 8.4 per cent of Norway's GDP, ${ }^{59}$ Norwegian objectives and measures at the time were in line with the AMSA recommendations, focusing on safety, emergency preparedness, and environmental protection. In spite of this, the AMSA findings quickly gained momentum. ${ }^{60}$ In Arctic shipping, however, Norway was ahead of other member states. Therefore, promoting Norwegian standards and greater cooperation within the Arctic Council became an important objective in national implementation. ${ }^{61}$ It is these aspects - the promotion of Norwegian standards and cooperation - that are the focus of the AMSA analysis below. Here we can note a slight difference: while the ACIA generated national implementation measures aimed at national actors, Norway's objectives related to the AMSA recommendations centered on influencing the policies of other member states.

The three particular AMSA recommendations under scrutiny are included because member states were specifically requested to initiate appropriate follow-up measures within their national implementation processes. ${ }^{62,63}$

Table 2. The AMSA recommendations

Reduce Air Emissions: That the Arctic states decide to support the development of improved practices and innovative technologies for ships in port and sea to help reduce current and future emissions of greenhouse gases (GHGs), nitrogen oxides (NOx), sulfur oxides (SOx) and particulate matter (PM), taking into account the relevant IMO regulations.

Arctic Marine Traffic System: That the Arctic states should support continued development of a comprehensive Arctic marine traffic awareness system to improve monitoring and tracking of marine activity, to enhance data sharing in near real-time, and to augment vessel management service in order to reduce the risk of incidents, facilitate response and provide awareness of potential user conflict. The Arctic states should encourage shipping companies to cooperate in the improvement and development of national monitoring systems.

Survey of Arctic Indigenous Marine Use: That the Arctic states should consider conducting surveys on Arctic marine use by indigenous communities where gaps are identified, to collect information for establishing up-to-date baseline data to assess the impacts from Arctic shipping activities.

Source: PAME, Arctic Marine Shipping Assessment Report (2009), pp. 6-7

\subsection{National implementation}

Recommendation: Reduce air emissions

"Reduce air emissions" requested member states to reduce their current and future emissions of greenhouse gases (GHGs), nitrogen oxides (NOx), sulfur oxides ( $\mathrm{SOx}$ ), and particulate matter (PM) from ships. ${ }^{64}$ However, reduction of ship emissions to the atmosphere had already been on the Norwegian agenda for quite some time - the 2007 heavy fuel oil (HFO) ban is an illustrative example. ${ }^{65}$ As regards implementing the AMSA recommendation, an important national measure appears to be the promotion of this ban to other member states. 


\section{Ida Folkestad Soltvedt}

In 2010, the Norwegian Maritime Authority (NMA) was requested to assist the Norwegian delegation to PAME and the Ministry of the Environment in following up the AMSA report. The NMA was specifically instructed to participate in PAME's workings, and to promote the Norwegian standpoint regarding an early ban on the use and carriage of HFO in Arctic waters. The final objective was to promote a joint proposal to the International Maritime Organization. ${ }^{66}$ The same message was repeated in subsequent years and appears to have set the stage for a Norwegian initiative within the Arctic Council: ${ }^{67}$ Before the end of 2010, the Norwegian delegation to PAME had proposed a project to compile existing knowledge on the use and carriage of $\mathrm{HFO}$ in the Arctic. ${ }^{68}$ The project would investigate the consequences of HFO in terms of potential spills and air pollution, including the formation of black carbon. ${ }^{69}$ It resulted in three reports, the final of which was issued in 2013.

Considering the implementation measure just reviewed, how can the characteristics and malignancy of this AMSA recommendation help explain the outcome? Firstly, the recommendation is not precise - it does not specify any measures for achieving the objective of reducing emissions. By allowing for interpretation and leeway, such lack of precision could be expected to hamper national implementation. In this case, however, imprecision appears to have worked in favor of Norwegian preferences. Given the disagreement among member states, specifying a ban on HFO within the recommendation would have been impossible, ${ }^{70}$ whereas vagueness may have facilitated the promotion of a ban regardless of divergent member-state preferences.

Moreover, the recommendation was non-malignant - at least within the national context of Norway. An HFO ban, characterized by broad consensus, had already been established. Norway had also played an important role in the establishment of such a ban in the Antarctic, ${ }^{71}$ which suggests that arriving at the subsequent decision to promote a similar ban within the Arctic Council was relatively easy.

Concerning stakeholder involvement, the norm-development process within the Arctic Council was marked by broad participation, including indigenous peoples' groups through the permanent participants, environmental organizations, and actors from the industrial sector. Some of these stakeholders also played a role in subsequent processes initiated by Norway. By evaluating cargo flows, risks and the environmental impacts of shipping, Det Norske Veritas GL (DNV GL)--an international classification body--helped define the initial problem of atmospheric emissions during the AMSA process. ${ }^{72}$ When the Norwegian HFO project was accepted by member states in 2010, DNV GL was approached as a consultant and tasked to carry out the assessment reports. ${ }^{73}$ This shows how DNV GL, which was involved in the AMSA process, was accorded a role in Norwegian follow-up activities; thus, DNV GL may be seen as a contributor in implementing the recommendation.

The WWF was also involved in developing the AMSA recommendations, and emphasized the need to identify vulnerable areas. ${ }^{74}$ After the AMSA process, WWF stressed how HFO could damage sensitive areas within the Arctic. ${ }^{75}$ Moreover, WWF directly criticized the Norwegian government for inadequately promoting such a ban among the Arctic Council member states. ${ }^{76}$ 
Finally, monitoring was influential in terms of implementation, but not in line with the 'naming and shaming' paradigm. Rather, the AMSA reporting system helped keep the issue on the agendas of Norway and the Arctic Council. By extension, it became easier to propose solutions on how best to deal with the recommendation. ${ }^{77}$

In summation: the positive implementation outcome seems to have been facilitated by the involvement of stakeholders, the reporting system, and the absence of malignancy. Moreover, the very imprecision of the recommendation appears to have had a positive effect on implementation.

\section{Recommendation: Arctic marine traffic system}

As with the recommendation discussed above, the recommendation "Arctic marine traffic system" did not introduce policies that were new to Norway. Although member states were requested to support the development of an Arctic marine traffic system, the Norwegian framework was already extensive. In particular, Norway's use of AIS and its security measures was superior to the situation in the other Arctic states. $^{78}$ Yet, the recommendation does appear to have launched the idea of developing a common system, where member states could share information and obtain a more holistic picture of Arctic shipping. In 2013, the Ministry of Foreign Affairs published a report on the consequences for Norway of increased Arctic shipping. The report pointed out that data on Arctic ship traffic was not collected systematically, nor regularly shared among the Arctic states. ${ }^{79}$ The government was therefore advised to develop a joint monitoring and warning satellite-based system for the Arctic Ocean. BarentsWatch - a monitoring and information system placed in the Arctic - was proposed as one platform for developing such Arctic cooperation. ${ }^{80}$ In 2014, this advice was presented to the Arctic Council: during a PAME meeting, Norway offered to provide raw and processed satellite AIS data to the Council. ${ }^{81}$ That same year, PAME initiated a new project, Arctic Shipping Data Service (ASDS), aimed at updating Arctic ship traffic data for use in assessments and trend analysis. ${ }^{82}$ Norway and the USA were appointed lead countries. Under the ASDS project, Norway informed the member states of its own political measures, including extensive presentations of BarentsWatch and Havbase - another system based on AIS data. ${ }^{83}$ Norway also presented an update on ship traffic in the high seas areas of the Central Arctic Ocean, in line with its 2014 proposal. ${ }^{84}$ Then in 2016, ASDS was reframed; the USA took charge, with project completion expected in $2017 .{ }^{85}$

We may now ask: how did the three characteristics of precision, stakeholder involvement and monitoring, plus malignancy, affect the outcome? This AMSA recommendation was precise. Its precision, however, did not have any effect on implementation activities: It specified measures for achieving the objective of a ship-traffic system, but such measures had already been implemented by Norway. On the other hand, the absence of malignancy may have helped national implementation. As Norway had basically fulfilled the recommendation already, there must have been broad national consensus on the importance of traffic monitoring. Moreover, the recommendation would entail few additional expenses. Such a 


\section{Ida Folkestad Soltvedt}

situation is likely to have eased the role that Norway assumed within the Arctic Council.

Further, the involvement of stakeholders - indigenous peoples, environmental organizations and industry - in the AMSA norm-development process does not seem to have affected the outcomes of national implementation. At least no trace of their participation in the national processes has been found.

However, monitoring did facilitate national implementation. By 2014, all AMSA recommendations had gained momentum within the Arctic Council, and the PAME agenda was governed and structured by the recommendations. ${ }^{86}$ This made it easier to provide suggestions on how to implement the recommendation.

In summary, then, the positive implementation outcome of this recommendation appears only to have been influenced by the reporting system and the absence of malignancy.

\section{Recommendation: Survey of Arctic indigenous marine use}

Unlike the two foregoing AMSA recommendations, the third one, "survey of Arctic indigenous marine use", did not result in any national implementation measures. Here it was argued that a survey had been conducted in 2008, when the Coastal Fishing Committee investigated the rights of the Saami people and Arctic residents to fish in the coastal areas of Finnmark county. ${ }^{87}$ This argument, however, is a source of disagreement. Although the Coastal Fishing Committee concluded that Saami and other residents had such rights, little was done by the government to ensure proper follow-up, ${ }^{88}$ and the Coastal Fishing Committee did not conduct an actual survey on the Saami's traditional marine use of the area. Despite the absence of implementation measures, this case-like the recommendations discussed abovestill shows that our three characteristics and malignancy have explanatory power.

First of all, this third recommendation was not precise: It merely stated the objective of conducting surveys on Arctic indigenous marine use-without specifying the measures necessary to achieve it. Imprecise recommendations allow for leeway and discretion and, therefore, run the risk of not being implemented. Norwegian authorities apparently took advantage of the recommendation's imprecise formulation, using it to justify the Coastal Fishing Committee's activities as implementation - thereby obviating the need to initiate other additional measures.

Moreover, the recommendation touched on a rather sensitive issue: Whereas the national authorities claimed that a survey had been conducted, the Saami Councila permanent participant of the Arctic Council — argued against this. According to the Saami Council, the lack of additional implementation measures was rooted in the question of indigenous peoples' rights - an issue the government was unwilling to address. ${ }^{89}$ Although it is difficult to determine the economic costs such a survey would entail, this disagreement shows that political costs were present. Thus a certain level of malignancy existed, serving to obstruct the national implementation process. 
As for stakeholder involvement, the Saami Council contributed actively to the AMSA project, resulting in recommendations that reflected the views of the Council. ${ }^{90}$ Moreover, the Saami Council played an active role in promoting this recommendation to the national authorities. When attempts to persuade national decision-makers failed, the Saami Council pursued an alternative direction. Together with the Aleut International Association (AIA), ${ }^{91}$ the report 'Development of an Arctic Marine Use Survey Process' was submitted to PAME. ${ }^{92}$ The report was intended as a study on which later measures could be based and as a way of approaching the topic without inflicting a disfavorable politically situation on Norway. ${ }^{93}$ However, due to lack of resources, the Saami Council was unable to continue participating in the project. ${ }^{94}$ All the same, the course of events shows how stakeholders involved in Arctic Council processes may attempt to influence national implementation processes.

As regards the implementation measures pursued by the Saami Council, monitoring - the reporting system-was important. The recommendation was already part of the PAME agenda and was therefore difficult to overlook. ${ }^{95}$

Thus, we find that both stakeholder involvement and monitoring were of importance in this case, even though implementation did not come about. Both the imprecision of the recommendation and its malignancy are likely to have hindered such implementation processes in unfolding nationally.

\section{Summary}

Due to its position as a leading maritime power, Norway had already implemented much of what AMSA came to recommend, before the report was released. However, the shipping sector is international in scope, and how other Arctic states operate affects Norwegian industry, climate and environment. Norway therefore followed up the AMSA recommendations by promoting its own national standards and greater member-state cooperation. The recommendations "reduce air emissions" and "Arctic marine traffic system" were implemented, whereas "survey of Arctic indigenous marine use" did not result in any such measures.

As for the characteristics and malignancy of the AMSA recommendations, precision did not have any conclusive effect on implementation outcomes. Because Norway had already fulfilled most of the requirements, any clarification of measures to be taken had little significance. In fact, the absence of precision may have had a positive impact on the implementation of the recommendation "reduce air emissions": since the recommendation was formulated in a way that provided leeway, Norway was able to pursue a solution that was not part of the recommendationdespite divergent member-state preferences. The effect of malignancy, on the other hand, was consistent across the recommendations. When present, malignancy had a hampering effect on implementation, whereas absence of malignancy favored positive implementation outcomes. In addition, stakeholder involvement emerged as important in connection with the recommendations "reduce air emissions" and "survey of Arctic indigenous marine use." Finally, we note the importance of monitoring, 


\section{Ida Folkestad Soltvedt}

which served as an agenda-setter both within the Arctic Council and at the national level.

\section{Conclusions and implications}

Starting from the assumptions that international law is not binary, that soft law is not a uniform phenomenon, and that certain characteristics of the recommendationsprecision, monitoring and stakeholder involvement-may enhance implementation, what conclusions can be drawn?

First and foremost, Norway as a member state of the Arctic Council devoted considerable effort to implementing several of the Council's recommendations. Implementation, however, was pursued in two very distinct ways. The ACIA put adaptation on the national agenda, while the AMSA came into play in a different domestic context. Consequently, the ACIA process led to national measures conducted within national borders and directed at national actors. As to the AMSA process, Norway constituted a maritime power and had already implemented most of the measures proposed in the AMSA's recommendations. Therefore, an important implementation objective for Norway became the promotion of national standards and greater cooperation within the Arctic Council.

Of the six recommendations examined here, four - two from ACIA, and two from AMSA - generated implementation measures in Norway. This study indicates that three specific characteristics of the recommendations, along with the presence or absence of malignancy, did influence some of the outcomes. Although the effects of precision proved ambiguous, both monitoring of state behavior and stakeholder involvement appear to have affected implementation positively - if the issues were non-malignant. When malignancy was present, there was no implementation.

While these findings are interesting in their own right, they also speak to the debate on the effectiveness of the Arctic Council and to the scholarly literature on effectiveness more generally. In contrast to assumptions that the Arctic Council, as a soft-law body, cannot be effective, this study has shown how recommendations from two significant reports were implemented in Norway. Although other aspects are also relevant, the structural and organizational characteristics of the Arctic Council's recommendations emerge as important explanatory factors, as long as the issue is not overly demanding. With regard to the literature on effectiveness more generally, this study has shown that characteristics often associated with hard-law agreements may be equally relevant in the application of soft-law commitments. Ultimately, then, the differences between the two may not be as great as often claimed. By extension, it is not necessarily so that hard law is more effective for ensuring implementation than soft law.

\section{ACKNOWLEDGEMENTS}

I would like to thank Olav Schram Stokke and Svein Vigeland Rottem, as well as the two anonymous reviewers, for their insightful and constructive feedback. 


\section{NOTES}

1. Paula Kankaanpää \& Oran R. Young,'The effectiveness of the Arctic Council', Polar Research 31 (2012), pp. 1-14; Timo Koivurova \& Erik J. Molenaar, International Governance and Regulation of the Marine Arctic: Overview and Gap Analysis (2009), pp. 1-43; Timo Koivuriva \& David Vanderzwaag, 'The Arctic Council at 10 years: Retrospect and prospect', University of British Columbia Law Review 40/1 (2007), pp. 121-194.

2. The few exceptions include Timo Koivurova, 'Implementing guidelines for environmental impact assessment in the Arctic', in C. J, Basmeijer \& T. Koivurova (eds), The Theory and Practice of Transboundary Environmental Impact Assessment (Leiden: Nijhoff, 2008), pp. 151-174; Kristine Offerdal, 'Oil gas and the environment, in O. S. Stokke \& G. Hønneland (eds), International Cooperation and Arctic Governance: Regime Effectiveness and Northern Region Building (Abingdon: Routledge, 2007), pp. 138-136; Nathaniel P. Valk, Arctic Council Soft Law: An Effective Analysis (2012), pp. 1-55; and Jessica F. McGrath, Evaluating Arctic State Implementation of Ecosystem-Based Management Recommendations Supported by the Arctic Council: Canada Norway, and the US (2014), pp. 1-55.

3. The ACIA and the AMSA were selected according to a set of criteria: They both include policy recommendations (something which have become more common in later years), a significant amount of time has passed since their release, and they allow for variation among the independent variables studied in this article.

4. Arild Underdal, 'Meeting common environmental challenges: The co-evolution of policies and practices', International Environmental Agreements: Politics, Law and Economics 13/1 2013, pp. 15-30.

5. An elaboration on this point will be given in section 4.1 and 5.1 .

6. Geir Hønneland \& Anne-Kristin Jørgensen, Implementing International Environmental Agreements in Russia (Manchester: Manchester University Press, 2003), p. 29.

7. Steinar Andresen, Jon Birger Skjærseth \& Jørgen Wettestad, Regime, the State and Society: Analyzing the Implementation of International ENvironmental Commitments, IIASA Working Paper (1995), p. 3; Kenneth Hanf, 'The domestic basis of international environmental agreements', in A. Underdal \& K. Hand (eds), International Environmental Agreements and Domestic Politics - The case of acid rain (Aldershot: Ashgate, 2000), pp. 13-14; David Victor, Kal Raustiala, Eugene B. Skolnikoff, The Implementation and Effectiveness of International Environmental Commitments: Theory and Practice (Cambridge: MIT Press, 1998), p. 15.

8. Victor, Raustiala \& Skolnikoff, The Implementation and Effectiveness of International Environmental Commitments: Theory and Practice, p. 7.

9. One alternative understanding is that of Michael W. Reisman (1988), who recognizes the "sliding scale of hardness or softness in all norms" - largely (as will be shown), paralleling the point of view tabled in this article. However, although Reisman views soft law as "performing certain positive functions" he, like many others, concludes that most of the law made this way "cannot be fulfilled in any effective fashion". I, on the other hand, am of the opinion that the characteristics a soft law norm holds - the degree of hardness or softness if you will - is essential in determining exactly how effectively norms can and will be fulfilled.

10. Daniel Thürer, 'Soft law', in R. Bernhardt (ed.), Encyclopedia of Public International Law (Amsterdam: Elsevier, 2000), pp. 452-460 at pp. 452-454.

11. Gregory C. Shaffer \& Mark A. Pollack, 'Hard vs. soft law: Alternatives, complements and antagonists in international governance', Minnesota Law Review 94/3 (2009), pp. 706-799 at p.707, 713 .

12. Kenneth Abbott \& Duncan Snidal, 'Hard and soft law in international governance', International Organization 54/3 (2000), pp. 421-456 at p. 424.

13. Kenneth Abbott, Robert Keohane, Andrew Moravcsik, Anne-Marie Slaughter \& Duncan Snidal, 'The concept of legalization', International Organization 54/3 (2000), pp. 401-419 at p. 401 . 


\section{Ida Folkestad Soltvedt}

14. Abbott, Snidal, 'Hard and soft law in international governance', p. 421.

15. Ibid., p. 422

16. Edith B.Weiss \& Harold Jacobson, Engaging Countries: Strengthening Compliance with International Environmental Accords (Cambridge: MIT Press, 1998); Victor, Raustiala, Skolnikoff, The Implementation and Effectiveness of International Environmental Commitments: Theory and Practice; Dinah Shelton, 'Introduction: Law, non-law and the problem of "soft law", in D. Shelton (ed.), Commitment and Compliance: The Role of Non-Binding Norms in the International Legal System (Oxford: Oxford University Press, 2003), pp. 1-18; Jürgen Friedrich, International Environmental 'SoftLlaw': The Functions and Limits of Nonbinding Instruments in International Environmental Governance and Law (Berlin: Springer, 2013).

17. Abbott, Keohane, Moravcsik, Slaughter, Snidal, 'The concept of legalization', p. 401.

18. Ibid., p. 412.

19. Thomas M. Franck, The Power of Legitimacy Among Nations (Oxford: Oxford University Press, 1990), p. 52.

20. Ronald B. Mitchell, 'Sources of transparency: Information systems in international regimes', International Studies Quarterly 42/1 (1998), pp.109-130 at p. 109.

21. Shelton, Commitment and Compliance: The Role of Non-Binding Norms in the International Legal System, p.15.

22. Friedrich, International Environmental 'Soft Law': The Functions and Limits of Nonbinding Instruments in International Environmental Governance and Law, p. 269.

23. Olav Schram Stokke, 'Asian stakes and arctic governance', Strategic Analysis 38/6 (2014), pp. 770-78 at p. 770; R. Edward Freeman, Strategic Management: A stakeholder approach (Boston: Pitman, 1984), p. 46.

24. Piotr Graczyk \& Timo Koivurova, 'The Arctic Council', in L. C. Jensen \& G. Hønneland (eds), Handbook of the Politics of the Arctic (Cheltenham: Edward Elgar, 2015), pp. 298-327 at p. 313.

25. Except for voting rights, permanent participants have the same privileges as member states in political processes, including full consultation in connection with negotiations and decisions.

26. Observers are invited to attend meetings, but may make statements only at the discretion of the chair.

27. Arild Underdal, 'Meeting common environmental challenges: The co-evolution of policies and practices'; Olav Schram Stokke, Disaggregating International Regimes: A New Approach to Evaluation and Comparison (London: MIT Press, 2012), p. 52.

28. Timo Koivurova, 'Limits and possibilities of the Arctic Council in a rapidly changing scene of governance', Polar Record 46/2 (2010), pp. 149-156, at p. 149.

29. Arctic Council, ACIA Policy Document (2004) [Online]. Available at: http://www.acia.uaf. edu/PDFs/ACIA_Policy_Document.pdf [14 May 2016].

30. E. Carina H. Keskitalo, Timo Koivurova \& Nigel Bankes, 'Climate governance in the Arctic: Introduction and theoretical framework, in: T. Koivurova, E. C. H. Keskitalo \& N. Bankes (eds), Climate Governance in the Arctic (Dordrecht: Springer, 2009), pp. 1-26 at p. 10; Alf Håkon Hoel, 'Climate change', in O. S. Stokke \& G. Hønneland (eds), International Cooperation and Arctic Governance: Regime Effectiveness and Northern Region Building (Abingdon: Routledge, 2007), pp. 112-137 at p. 114, 132.

31. Roger Pielke, Gwyn Prins, Steve Rayner \& Daniel Sarewitz, 'Lifting the taboo on adaptation', Nature 445/8 (2007), pp. 597-598 at p. 597; Koivurova, 'Limits and possibilities of the Arctic Council in a rapidly changing scene of governance', pp. 149. As an additional note: Although the existing climate regime, including the UNFCCC, did address both mitigation and (to a lesser extent) adaptation, adaptation was largely perceived as something necessary only for developing countries and, therefore, as less relevant to developed states. 
32. Koivurova, 'Limits and possibilities of the Arctic Council in a rapidly changing scene of Arctic governance', p. 149.

33. Report No. 41 (1994-1995) Om norsk politikk mot klimaendringer og utslipp av nitorgenoksider [Online]. Available at: https://www.stortinget.no/no/Saker-og-publikasjoner/ Stortingsforhandlinger/Lesevisning/?p=1994-95\&paid=3\&wid=d\&psid=DIVL516 [20 May 2016].

34. Report No. 15 (2001-2002). Tilleggsmelding til St.meld. nr. 54 (2000-2001) Norsk klimapolitikk [Online]. Available at: https://www.regjeringen.no/contentassets/471533eed2ff47f987699d32b 8207043/no/pdfa/stm200120020015000dddpdfa.pdf [20 May 16], p. 62.

35. Norwegian Polar Institute, Arctic Climate Impact Assessment. Presentasjoner og oppsummeringer fra fagmøtet Effekter av klimaendringer med spesielt fokus på Barentshavet (2003) [Online]. Available at: https://brage.bibsys.no/xmlui//bitstream/handle/11250/172936/Internrapport14. pdf?sequence=1 [09 May2016], p. 13.

36. Arctic Council, ACIA Policy Document (2004) [Online], pp. 5-6.

37. Norwegian Polar Institute, NorACIA. Norsk Oppfølging av Arktisk Råd-Prosjektet 'Arctic Climate Impact Assessment': Handlingsplan 2006 (2006) [Online]. Available at: http:// docplayer.no/6253871-Noracia-norsk-oppfolging-av-arktisk-rad-prosjektet-arctic-climateimpact-assessment-handlingsplan-2006-2009.html [14 May 2016].

38. Ibid., p. 4.

39. Norwegian Polar Institute, Klimaendringer $i$ norsk Arktis: Kunnskapsbehov og tilpasningsstrategier for infrastruktur (2005) [Online]. Available at: http://noracia.npolar.no/litteratur/ rapport-fra-fagmote-om-klimaendringer-og-infrastruktur.pdf [9 May 2016]; Klimaendringer og tilpasningsstrategier for samiske nceringer (2005) [Online]. Available at: http://noracia. npolar.no/litteratur/rapport-fagmote-samisk-2005.pdf [9 May 2016]; Klimascenarier for norsk Arktis (2006) [Online]. Available at: http://noracia.npolar.no/fagmoter/foredragenefra-klimascenariedagen-12-12.html [9 May 2016]; Klimaendringer i norsk Arktis - ekstremvar og konsekvenser for samfunnet (2007) [Online]. Available at: http://noracia.npolar.no/ fagmoter/foredragene-fra-ekstremverseminaret.html [9 May 2016].

40. Ibid.

41. Norwegian Ministry of Foreign Affairs, The Norwegian Government's High North Strategy (2006) [Online]. Available at: https://www.regjeringen.no/globalassets/upload/UD/Vedlegg/ strategien.pdf [9 May 2016], p. 37.

42. Report No. 28, (2007-2008) Sami Policy [Online]. Available at: https://www.regjeringen.no/ contentassets/8e1e26b083304fa394b6495db574a060/no/pdfs/stm200720080028000dddpdfs. pdf [20 May2016], p. 41.

43. Interview, Permanent Participant, 2016.

44. Annika E. Nilsson, 'A changing Arctic climate: Science and policy in the Arctic Climate Impact Assessment', in T. Koivurova, E. C. H. Keskitalo \& N. Bankes (eds), Climate Governance in the Arctic (Dordrecht: Springer, 2009) pp. 77-95 at p. 87; Interview, 2016.

45. Arctic Athabaskan Council, Gwich'in Council International, Saami Council, Russian Association of Indigenous Peoples of the North, Inuit Circumpolar Conference, Aleut International Association, Time for Action on Climate Change: A Statement by Arctic Indigenous Peoples (2004) [Unpublished]; Indigenous Peoples Urge Arctic States to Take Steps in Addressing Climate Change, Following Policy Release (2004) [Unpublished].

46. Interview, Permanent Participant, 2016.

47. Interview, Permanent Participant, 2016.

48. WWF, Arktisk Råd og den politiske oppfolgingen av ACIA-rapporten (2004) [Unpublished].

49. Arctic Council, ACIA Policy Document (2004) [Online], p. 6.

50. Signe Nybø, Karl-Birger Strann, Jarle W. Bjerke, Hans Tømmervik, Dagmar Hagen \& Annika Hofgaard, Tilpasninger til klimaendringer $i$ Nord-Norge og på Svalbard. Vurdering av 
vernebehovet og terrestriske økosystemers evne til å binde karbon (2009) [Online]. Available at: http://www.nina.no/archive/nina/PppBasePdf/rapport/2009/436.pdf [14 May 2016], pp. 3-4.

51. Interview, Government Official, 2016.

52. Kyrre Groven, Hogne Satøen \& Carlo Aall, Regional klimasårbarheitsanalyse for Nord-Norge. Norsk oppfølging av Arctic Climate Impact Assessment (NorACIA) (2009) [Online]. Available at: http://noracia.npolar.no/noracia-prosjekter-2/rapport-vestlandsforskning-2006-regionalsarbarhet.pdf [14 May 2016].

53. Arctic Council, ACIA Policy Document (2004) [Online], p. 6.

54. Interview, Permanent Participant and Government Officials, 2016.

55. Susan J. Hassol, Impacts of a Warming Arctic. Arctic Climate Impact Assessment (Cambridge: Cambridge University Press, 2004), p. 8.

56. Timo Koivurova, 'Governing Arctic shipping: Finding a role for the Arctic Council', The Yearbook of Polar Law 2/1 (2010), pp. 115-138 at p. 128.

57. PAME, Arctic Marine Shipping Assessment 2009 Report (2009), p. 4.

58. Ibid., pp. 6-7.

59. For more information, see https://www.regjeringen.no/en/id4/ or https://www.rederi.no/en/.

60. Norwegian Ministry of Foreign Affairs, New Building Blocks in the North: The Next Step in the Government's High North Strategy (2009) [Online]. Available at: https://www.regjeringen.no/ globalassets/upload/ud/vedlegg/nordomradene/new_building_blocks_in_the_north.pdf [9 May 2016]; Norwegian Ministry of Foreign Affairs, The High North: Visions and Strategies (2011) [Online]. Available at: https://www.regjeringen.no/globalassets/upload/ud/vedlegg/nordomradene/ud_nordomrodene_en_web.pdf [9 May 2016]; Report No. 26 (2012-2013) National Transport Plan (2014-2023) [Online]. Available at: https:/www.regjeringen.no/contentassets/ e6e7684b5d54473dadeeb7c599ff68b8/en-gb/pdfs/stm201220130026000engpdfs.pdf [20 May 2016]; Norwegian Ministry of Trade and Industry, Regjeringens Maritime Strategi. Stø Kurs 2020 (2013) [Online]. Available at: https://www.regjeringen.no/globalassets/upload/nhd/temasider/ maritime_naringer/maritimstrategistokurs2020.pdf [28 April 2016]; Norwegian Ministry of Foreign Affairs, Økt skipsfart $i$ Polhavet - muligheter og utfordringer for Norge (2013) [Online]. Available at: https://www.regjeringen.no/globalassets/upload/ud/vedlegg/nordomrc3a5dene/ oekt_skipsfart_i_polhavet_rapport.pdf [29 April 2016].

61. Interview, Government Officials, 2016.

62. PAME, PAME Working Group Meeting Report No: PAME I-2009 (2009) [Online]. Available at: http://www.pame.is/images/02_Document_Library/Meeting_Reports/PAME_I-2009 Report._samsett.pdf [18 May 2016], p. 5.

63. A short elaboration is at this point needed. The category did initially include seven recommendations. However, several of these recommendations were excluded from the analysis. Three of them - 'engagement with Arctic communities', 'protection from invasive species' and 'addressing the infrastructure deficit' - due to space limitations and to they being of less relevance to Norway. The last one, 'investing in hydrographic, meteorological and oceanographic data', was also excluded due to space limitations. Yet, it was included in the larger study on which this article is based. In that respect, the findings indicated that implementation measures had been initiated, but that the characteristics had few bearings on the outcome.

64. PAME, Arctic Marine Shipping Assessment 2009 Report (2009), p. 6.

65. The ban introduced in 2007 covered the nature reserves on the eastern side of Svalbard. In 2009 the ban was expanded to the reserves on the western side of Svalbard.

66. Norwegian Ministry of Environment, Tildelingsbrev 2010 til Sjøfartsdirektoratet (2010) [Online]. Available at: https://www.sjofartsdir.no/Global/Om\%20Sdir/Presentasjon $\% 20 a v \% 20$ direktoratet/TIldelingsbrev $\% 20 \mathrm{fra} \% 20 \mathrm{NHD} \% 20 \mathrm{og} \% 20 \mathrm{MD} /$ Endelig $\% 20$ tildelingsbrev $\% 20$ MD\%202010.pdf [20 April 2016], p. 9. 
67. Norwegian Ministry of Environment, Tildelingsbrev 2011 til Sjøfartsdirektoratet (2011) [Online]. Available at: https://www.regjeringen.no/globalassets/upload/md/2011/vedlegg/ brev/tildelingsbrev_2011/tildelingsbrev_sjofartdir.pdf [20 April 2016]; Endelig tildelingsbrev 2012 for Sjøfartsdirektoratet (2012) [Online]. Available at: https://www.regjeringen.no/ contentassets/7999c83ccc2a4fc39121d776172b7257/sjofartsdirektoratet_2012.pdf [20 April 2016]; Endelig tildelingsbrev 2013 for Sjofartsdirektoratet (2013) [Online]. Available at: https:// www.regjeringen.no/contentassets/eac76c5b603a4ceebfdd7153b5cf5d2f/sjofartsdirekoratet_ tildelingsbrev_2013.pdf [20 April 2016]; Tildelingsbrev 2014 for Sjøfartsdirektoratet (2014) [Online]. Available at: https://www.regjeringen.no/globalassets/upload/kld/tildelingsbrev/ sjofartsdir_tildelingsbrev_2014.pdf [20 April 2016].

68. PAME, PAME Working Group Meeting Report No: PAME I-2009 (2010) [Online]. Available at: http://www.pame.is/images/02_Document_Library/Meeting_Reports/PAME_I-2009 Report._samsett.pdf [18 May 2016], annex II.

69. Ibid.

70. Interview, Government Officials, 2016.

71. Following a proposal by Norway, a chapter banning the use and carriage of HFO in the Antarctica was added to MARPOL in 2010.

72. PAME, Program for the Protection of the Arctic Marine Environment PAME (2006) [Online]. Available at: http://www.pame.is/images/02_Document_Library/Meeting_Reports/PAME \%20report\%20I-2006.pdf [18 May 2016], appendix V-1.

73. PAME, Heavy Fuel in the Arctic (2016) [Online]. Available at: http://www.pame.is/images/ 02_Document_Library/Meeting_Reports/2016/PAME_I_2016_Meeting_Report.pdf [21 May 2016].

74. PAME, Program for the Protection of the Arctic Marine Environment PAME (2005) [Online]. Available at: http://www.pame.is/images/02_Document_Library/Meeting_Reports/PAME\% 20report\%20II-2005.pdf [18 May 2016], p. 8; Program for the Protection of the Arctic Marine Environment PAME (2006) [Online], p. 8.

75. WWF, Beskyttelse av Arktis lagt på is (2012) [Online]. Available at: http://www.wwf.no/? 35505/Beskyttelse-av-Arktis-lagt-p-is [19 May 2016]; WWF ber om tungoljeforbud i Arktis (2013) [Online]. Available at: http://www.wwf.no/?39268/WWF-ber-om-tungoljeforbud-iArktis [21 April 2016]; WWFs løsninger for Arktis (n.d.) [Online]. Available at: http://www. wwf.no/dette_jobber_med/hav_og_kyst/arktis/wwfs_losninger_for_arktis/ [15 April 2016].

76. WWF, WWF ber om tungoljeforbud $i$ Arktis (2013) [Online].

77. Interview, Government Officials, Arctic Council Working Group, 2016.

78. Interview, Government Officials, Arctic Council Working Group, 2016.

79. Norwegian Ministry of Foreign Affairs, Økt skipsfart i Polhavet - muligheter og utfordringer for Norge (2013) [Online]. Available at: https://www.regjeringen.no/globalassets/upload/ud/ vedlegg/nordomrc3a5dene/oekt_skipsfart_i_polhavet_rapport.pdf [29 April 2016], p. 8.

80. Ibid.

81. PAME, Working Group Meeting Report (2014) [Online]. Available at: http://www.pame.is/ images/02_Document_Library/Meeting_Reports/Meeting_Reports/PAME_II_2014_Meeting_ Report.pdf [1 May 2016], p. 5.

82. PAME, Final draft PAME Work Plan for the SAO Report to Ministers (2015) [Online]. Available at: https://oaarchive.arctic-council.org/bitstream/handle/11374/1472/PAME_ WORKPLAN_Doc2_Final_work_plan_2015-2017_AC_SAO_CA04.pdf?sequence $=2$ \&is Allowed=y [19 May 2016], p. 2.

83. Jon-Arve Røyset \& Bjørnar Kleppe, Historical AIS data - "Havbase" (2015) [Online]. Available at: http://pame.is/images/05_Protectec_Area/2015/PAME_2/Presentations/ AMSA_4.1_-_Havbase.pdf [19 May 2016]; Kjell Knudsen, Barentswatch (2015) [Online]. Available at: http://pame.is/images/05_Protectec_Area/2015/PAME_2/Presentations/AMSA_ 4.1_-_BarentsWatch_presentation.pdf [19 May 2016]. 


\section{Ida Folkestad Soltvedt}

84. Geir Høvik Hansen, Update on ship traffic in the high seas area of the Central Arctic Ocean (2015) [Online]. Available at http://pame.is/images/05_Protectec_Area/2015/PAME_2/ Presentations/AMSA_IID_-_Update_on_Ship_Traffic_in_the_High_Seas.pdf [19 May 2016].

85. PAME, Arctic Ship Traffic Data (ASTD) Project Plan (2016) [Online]. Available at: http:// www.pame.is/index.php/projects/arctic-marine-shipping/heavy-fuel-in-the-arctic-phase-i [1May 2016], pp. 2-3.

86. Interview, Government Official, 2016.

87. Interview, Government Official, 2016.

88. Interview, Permanent Participant, 2016; Øyvind Ravna, 'Samerett og samiske rettigheter i Norge', in Ø. Ravna \& T. Henriksen (eds), fuss i nord: hav, fiske og urfolk:En hyllest til det juridiske fakultet ved Universitetet $i$ Tromsøs 25-årjubileum (Oslo: Gyldendal juridisk, 2012), p. 162.

89. Interview, Permanent Participant, 2016.

90. Interview, Permanent Participant, 2016.

91. The Aleut International Association is a permanent participant of the Arctic Council.

92. Victoria Gofman \& Gunn-Britt Retter, Development of an Arctic Indigenous Marine Use Survey Process (2011) [Online]. Available at: http://www.pame.is/images/03_Projects/AMSA/ Arctic\%20Indigenous\%20Marine_Use_Survey_Process/Agenda_item_4_AMSA_IIA-Scoping Paper_Draft_Version_01_15_11.pdf [6 May 2016].

93. Interview, Permanent Participant, 2016.

94. Interview, Permanent Participant, 2016.

95. Interview, Permanent Participant, 2016. 